\title{
Effect of Dental Braille Education (Dbe) on Oral Health Knowledge and Attitudes on Children with Visual Impairment
}

Görme Engelli Çocuklarda Dental Braille Eğitiminin Ağız Sağlığı ve Tutumları Üzerindeki Etkileri

\author{
Reieza Zulfahmi TAFTAZANI',Muhammad Fiqih SABíLiLLAH', Tetet KARTiLAH', Cahyo \\ NUGROHO', Hadiyat MIKO' \\ ${ }^{1}$ Department of Dental Therapist, Polytechnic of Health Tasikmalaya, West Java, Indonesia \\ ${ }^{1}$ Dental Terapi Bölümü, Tasikmalaya Sağlık Politeknik Üniversitesi, West Java, Endonezya
}

\section{A B S TR ACT}

Purpose: This study aimed to analyze the influence of Dental Braille Education (DBE) on the oral health and hygiene knowledge and attitude of children with visual impairment. Material and Methods: Pre and post test research design was used. Dental Braille Education (DBE) was given to a sample and then evaluated again on day 21 . The results were compared by statisctical analysis. Results: This study was conducted on 12 child with visual impairment. No statistically significant difference were found between the oral health and hygiene knowledge $(Z=-3217$ and $p=0.001, p>0.05)$ and the attitudes $(Z=-2724$ and $p=0.006, p>0.05)$ of the sample. Conclusion: It can be concluded that the DBE education did not change the maintenance of oral health and improve the status of oral hygiene among children with visual disability. Further studies investigating the factors which may effect DBE education among children with visual impairment must be planned.

KeyWords: Oral health; Visually impaired persons

\section{öz}

Amaç: Bu çalışma, görme engeli olan çocuklarda Dental Braille Eğitiminin (DBE) çocukların oral sağlık ve hijyen ile ilgili bilgi ve tutumlarına olan etkisini analiz etmeyi amaçlamaktadır. Gereç ve Yöntem: Çalışmada pre-post test yönetemi kullanılmıştır. Çocuklar eğitim öncesi ve sonrası 21. günde değerlendirilmiştir. SonuçIar: Bu çalışma, görme engelli 12 çocuğa uygulanmıştır. Elde edilen sonuçlara göre eğitim öncesi ve sonrası çocukların bilgi düzeyi ( $Z=-3217$ ve $p=0.001, p>0.05$ ) ile tutumları $(Z=-2724$ ve $p=0.006, p>0.05)$ arasında istatiksel olarak anlamlı fark bulunmamıştır. Tartışma: Görme engelli çocuklara Braille yöntemi ile verilen eğitim çocukların oral sağlık ve hijyen ile ilgili bilgi ve tutumları üzerinde anlamlı değişikliğe neden olmamıştır. Bu popülasyonda oral sağlık ve hijyen eğitiminin başarısını etkileyen faktörlerin incelendiği ileri çalışmaların planlanması önerilmektedir.

Anahtar Kelimeler: Ağız sağlığı; Görme özürlü bireyler 
Wealth development aims to increase awareness, willingness and the ability of healthy life for everyone to realize the degree of public health as high, as an investment for the development of human resources socially and economically productive. Children with special needs, including people with disabilities is one of the nation's human resources of Indonesia whose quality should be improved in order to play a role, not only as the object of development but also the subject of development (Kemenkes, 2010).

Children with special needs are children who have limited or exceptionalism, whether physical, mental, intellectual, social and emotional, which gives them significant influence in the process of growth or development compared to other children the same age (Kemen-PPA, 2013). World Health Organization (WHO) estimates that the number of children with special needs in Indonesia is about $7-10 \%$ of the total number of children. According to data from the National Socioeconomic Survey (SUSENAS) in 2003, in Indonesia there are 679.048 school-age children with special needs or in other words the $21.42 \%$ of the total number of children with special needs (Kemenkes, 2010).

According to Susenas Quarter results (March 1,2011 ), the number of Indonesian children is as much as 82.98 million and 9.9576 million child is disabled. The number of children with special intelligence and special talent was $2.2 \%$ of the population of school-age children (4-18 years) or about 1.18556 million children (Kemen-PPA, 2013). Children with special needs need to be recognized and identified from a group of children in general, because they require specific services, such as medical services, special education and certain exercises that aim to reduce the limitations and dependency due to aberration suffered, and foster self-reliance to live in society (Kemenkes, 2010).

The children with special needs who require specific services are called children with visual impairment. The poor state of the oral cavity with visual impairment due to tooth brushing action is not monitored, other factors such as brushing technique, motor skills and mentoring assistance are still negligible (Reddy et al., 2014; Singh et al., 2014).

In this population oral hygiene is poor due to the presence of debris and plaque that can cause gingivitis and plaque while long-term exposure can cause loss of periodontal attachment. Long-term exposure plaque can also cause tooth demineralization and destruction, causing caries (Broadbent et al., 2011). Dental hygiene and poor oral functions can also cause plaque and calculus. Accumulation of bacterial plaque and contribution of deterioration of oral health is related to periodontal disease (Zeng et al., 2015).

According to a research from India the prevalence of dental caries and oral hygiene status among children with visual impairment is (40\%) (Ravishankar et al., 2013). While in Indonesia there are many children decreased with visual impairment level (50\%) and the rate of avarafe oral hygiene is about 2.3 medium categories (Agnintia et al., 2013). Dental and oral hygiene are poor at children with visual impairment due to three things: cariogenic food, gear position and the shape of a lack of knowledge about oral health in children with visual impairment due to lack of education on how to maintain dental and oral hygiene (Sheehy et al., 2004).

There are some methods to improve the oral hygiene in children with visual impairment such as toothbrushing education using a jaw model with assistance (Princess et al., 2014). Problems effecting oral health negatively during self care and home care are seen frequently among children with visual impairment (Agnintia et al., 2013). The the quality of handling the toothbrush to remove the dental plaque in children with visual impairment is not well in this population (Raiyani et al., 2014). The effectiveness of dental health education programs with and without involving the skills of oral hygiene in children with visual impairment is found important and also tactile techniques are seen important for visually impaired individuals. One method of teaching oral health is considered to be very precise and suitable for teaching materials in Braille brushing teeth is Dental Education (DBE) to visually impaired (Kadkhoda et al., 2014; Kumar et al., 2013)

Dental Braille Education (DBE) is a learning process in the field of oral health which is specialized for visually impaired. The aim of it is to teach oral health solutions to visually impaired individuals and also it is expected that the degree of oral health will be increased and improved after this education (Sabilillah et al., 2016).

According to limited literature there is little evidence based study on the effects of Dental Braille Education on children with disabilities. This study aimed to analyze the influence of Dental Braille Education (DBE) on the oral health and hygiene knowledge and attitude of children with visual impairment. 


\section{MATERIAL AND METHODS:}

Intervention is given on a sample in the form of Dental Braille Education (DBE) and then evaluated on day 21 . This study was conducted over 21 days in accordance with the theory in Carol Foster et al (2014), which states that health behavior change can be measured after 21 days. The sampling method in this study using purposive sampling method (Lawrence, 2006). The children were assessed twice; before and after the Dental Braille Education. The education included the basic oral health rules, brushing thecnics and using toothbrush. The results were compared with SPSS programme.

\section{RESULTS}

The characteristics of the participants is given in Table 1. Characteristics of respondents by sex can be seen in the table below:

Table 1. Characteristics of Participants

\begin{tabular}{|c|c|c|c|}
\hline No & Sex & $\mathbf{n}$ & \% \\
\hline $\mathbf{1}$ & Man & 4 & 33,3 \\
\hline $\mathbf{2}$ & Female & 8 & 66,7 \\
\hline Total & & 12 & 100 \\
\hline
\end{tabular}

Table 1 showed that four children (33.3\%) were male and 8 children (66.7\%) were female. Characteristics of survey respondents by sex majority female. Furthermore, the characteristics of survey respondents by the school can be seen in the table below:

Table 2. Characteristics of Respondents Based Research School

\begin{tabular}{|c|c|c|c|}
\hline No & School & $\mathbf{n}$ & \% \\
\hline $\mathbf{1}$ & SDLB & 6 & 50 \\
\hline $\mathbf{2}$ & SMALB & 6 & 50 \\
\hline \multicolumn{2}{|c|}{ Total } & 12 & 100 \\
\hline
\end{tabular}

Table 2 is based on the school characteristics of survey respondents indicate that as many as 6 children (50\%) in SDLB and as many as 6 children (50\%) in SMALB. Then performed bivariate analyzes. The bivariate analysis in this study aimed to test the hypothesis in this study. The hypothesis will be tested using the Wilcoxon non-parametric statistical tests to determine changes in knowledge and attitudes of the results to the results of the posttest pretest. The variables tested in this study will be outlined as follows:
Bivariate analysis, the variables of knowledge in this study can be seen in the table below:

Table 3. Changes Difference Analysis Knowledge of Results form posttest to pretest

\begin{tabular}{|c|c|c|}
\hline \multirow{2}{*}{ Variabel } & \multicolumn{2}{|c|}{ Wilcoxon } \\
\cline { 2 - 3 } & $\mathrm{Z}$ & $\mathrm{P}$ \\
\hline Knowledge posttest to pretest & -3.217 & 0.001 \\
\hline
\end{tabular}

Table 3 the results of analysis of the difference in changes in knowledge of the results of the posttest to pretest results showed no significant changes, as shown by $Z=-3217$ and $p=0.001$ (p>0.05).

\section{Attitude}

The bivariate analysis on attitudinal variables in this study can be seen in the table below:

Table 4. Difference in Attitude Change Analysis of Results form posttest to pretest

\begin{tabular}{|c|c|c|}
\hline \multirow{2}{*}{ Variabel } & \multicolumn{2}{|c|}{ Wilcoxon } \\
\cline { 2 - 3 } & $\mathrm{Z}$ & $\mathrm{p}$ \\
\hline Attitude posttest to pretest & -2.724 & 0.006 \\
\hline
\end{tabular}

Table 4 the results of analysis of the difference in attitude change from the posttest to pretest results showed no significant changes, as shown by $Z=-2724$ and $p=0.006$ ( $p>0.05)$.

\section{CONCLUSION}

This study was performed in children with visual impairment. Children with visual impairment is a general term that is used for individuals who have a disorder or obstacles in the sense of sight. Tools used for mobility for the children with visual impairment is a special rod with the color red and white horizontal stripes. As a result of loss or reduction in the function of the sense of sight, the children with visual impairment try to maximize the function of the sense of touch, smell, and hearing, so there are few children with visual impairment who have extraordinary ability in the field of music or science. A visually impaired person with impaired eyesight form of blindness overall (total) or partial (low vision).

According to the numbers of the participants in the study were gathered from a small but balanced group. This may help to present the effect of Dental Braille Education in aquite balanced way.

Based on analysis of the difference in changes in knowledge of the results of the posttest to pre- 
test results showed no significant changes, indicated by $Z=-3217$ and $p=0.001$ ( $p>0.05$ ). It is tought that teaching the strategies for the maintenance of oral health in the form of Dental Braille Education (DBE) can attract attention and easy to understand for the visually impaired and increased their knowledge of them. This result is similar to the results of Notoatmodjo (2012) which supports that the media as a tool for conveying health messages, the tool has a function in order to generate interest goals, achieve goals more, help in overcoming many barriers to understanding. This is also supported by Sabilillah et al (2016) which states that basically state intelligence children with visual impairment is not different from normal children but have trouble receiving information and perception, and therefore requires an approach and good communication in handling it. Knowledge in this study it can be concluded that the hypothesis that there was an effect Dental Braille Education (DBE) for knowledge in children with visual impairment is acceptable.

Further on attitudinal variables the study results showed no significant changes, indicated by $Z=-2724$ and $p=0.006$ ( $p>0.05$ ). It is touhgt that the reason for this is thought that attittudes can be affected by various factors such as cultural habits In the same line with Notoatmodjo (2003) which states that the attitude is a reaction or response of someone who is still closed to a stimulus or object. Manifestations attitudes can not be seen directly but can only be interpreted in advance of behaviors and attitudes usually closed based on the knowledge he has. Our results on attitude is also supported by the literature.

Our study has some limitations. The first and the biggest limitation of the thedy is the limited number of participants. This also help us to conclude the increase in level of knowledge and attitudes without statistically significant change. It is suggested that the same study must be planned in a larger group.

Based on the results of research it was concluded that the Dental Braille Education (DBE) changed the level of oral health and hygiene knowledge and attitudes in children with visual impairment but the change was not significant. Even this education can attract attention and easy to understand so may affect the respondents' knowledge new studies with more participants may be planned.

\section{REFERENCES}

Agnintia, D., Rachmawati, F., Arsita, R., \& Berti, P. L. (2014). 'Quality Self Care and Home Care' Solusi Kesehatan Gigi Dan Mulut Anak Tunanetra Di Sdlb
A-Ykab Surakarta. Program Kreativitas MahasiswaPengabdian Kepada Masyarakat.

Broadbent, J. M., Thomson, W. M., Boyens, J. V., \& Poulton, R. (2011). Dental plaque and oral health during the first 32 years of life. J Am Dent Assoc, 142(4), 415-426.

Maher, C. A., Lewis, L. K., Ferrar, K., Marshall, S., De Bourdeaudhuij, I., \& Vandelanotte, C. (2014). Are health behavior change interventions that use online social networks effective? A systematic review.J Med Internet Res, 16(2), e40.

Kadkhoda, Z., Rezaei, A., \& Amiri, A. (2014). Effect of visual impairment education on the improvement of oral hygiene and reduction of periodontitis prevalence. International Journal of Medical Dentistry, 4(2), 7.

Bina, D. B. K. A. D., Gizi, I. K. K. D. B., \& Anak, K. I. (2011). Pedoman pelayanan kesehatan anak di Sekolah Luar Biasa (SLB): bagi petugas kesehatan-[BUKU].

Perempuan, K. P. (2013). Panduan Penanganan Anak Berkebutuhan Khusus Bagi Pendamping (Orang Tua, Keluarga, dan Masyarakat).

Kumar, R. V., Fareed, N., \& Shanthi, M. (2013). The effectiveness of oral health education program with and without involving self-maintainable oral hygiene skills among the visually impaired children. Int J Sci Study, 1, 51-9.

Neuman, L. W. (2002). Social research methods: Qualitative and quantitative approaches.

Notoatmodjo, S. (2002). Metodologi Penelitian Kesehatan Jakarta: Rineka Cipta..(2007). Promosi kesehatan teori dan ilmu perilaku. Jakarta: Rineka Cipta.

Putri, M. H., \& Sirait, T. (2014). Pengaruh Pendidikan Penyikatan Gigi dengan Menggunakan Model Rahang Dibandingkan dengan Metode Pendampingan terhadap Tingkat Kebersihan Gigi dan Mulut Siswasiswi Tunanetra SLB-A Bandung. Majalah Kedokteran Bandung, 46(3), 134-142.

Raiyani, C. M., Arora, R., Deepak P.B., \& Dogra. S. (2014). Evaluation of efficacy of various types of toothbrush grips used to remove dental plaque by visually impaired children. Scholars Acad J Biosci, 2(11), 742-45.

Ravishankar, P. L., Jayapalan, C. S., Gondhalekar, R. V., Krishna, B. J., Shaloob, K. M., \& Ummer, P. F. (2013). Prevalence of dental caries and oral hygiene status among school going children: an epidemiological study.J Contemp Dent Pract, 14(4), 743- 746.

Reddy, V. K., Chaurasia, K., Bhambal, A., Moon, N., \& Reddy, E. K. (2013). A comparison of oral hygiene status and dental caries experience among institutionalized visually impaired and hearing impaired children of age between 7 and 17 years in central India. J Indian Soc Pedod Prev Dent, 31(3), 141.

Sabilillah, M.F., Taftazani, R.Z., Sopianah, Y., Fatmasari, D., 2016. Pengaruh Dental Braille Education (DBE) terhadap Oral Hygiene pada Anak Tunanetra. Tasikmalaya.

Sheehy, N et al., 2004. Volume 59 Number 5 May 2004. American Foundation for the Blind, 59(5), 1-27.

Singh, A., Kumar, A., Berwal, V., \& Kaur, M. (2014). Comparative study of oral hygiene status in blind and deaf children of Rajasthan. Adv Med Dent Sci, 2, 26-31.

Zeng, X. T., Leng, W. D., Zhang, C., Liu, J., Cao, S. Y., \& Huang, W. (2015). Meta-analysis on the association between toothbrushing and head and neck cancer. Oral Oncol, 51(5), 446-451.

i/S1368837515001268. 